\title{
Back to the Future in Acadian French
}

\author{
RUTH KING \\ York University \\ \& \\ TERRY NADASDI \\ University of Alberta
}

(Received November 2000; revised May 2003)

\begin{abstract}
AB STRACT
Our article presents a variationist analysis of future verb forms in Acadian French. The main variants considered are the inflected future (e.g. je partirai) and the periphrastic future (e.g. je vais partir). The purpose of this study is twofold: a) it will determine the distribution of these variants and their linguistic correlates; b) it will compare the use of future verb forms with other varieties of French. Our results reveal that the inflected future is used with greater frequency in Acadian French than in other Canadian varieties and that the factors that condition the variable in Acadian are not the same as in other varieties.
\end{abstract}

\section{INTRODUCTION}

The present article examines the expression of future temporal reference in Acadian French. Two principal variants are used with this function, namely, the periphrastic (aller 'to go' + infinitive, also known as the futur proche or 'near future') and the inflected (also known as the futur simple or 'simple future') future. The variable has been the subject of a number of studies of both European and Canadian French. For Quebec and Ontario French in particular, the case has been made that the inflected future has lost considerable ground to the periphrastic future including in contexts where traditional grammars prescribe the former. In our study we determine the overall distribution of the two variants in three varieties of Acadian French and consider the factors that influence variant choice. Our results show robust use of the inflected future and choice of variant correlated with a number of factors traditionally associated with such use, providing evidence of the conservative nature of the Acadian varieties.

\section{THE VARIABLE}

The two variants that have been the object of quantitative analysis in our study are presented in examples Ia) and $\mathrm{Ib}$ ): 
Ia) Periphrastic Future (PF)

Vous-autres, asteure, vous allez voir ça dans cinquante ans. (AV-25)

'You, now, you'll see that in fifty years.'

Ib) Inflected Future (IF)

Je crois bien qu'ils boiront ailleurs. (AC-6)

'I think they will drink elsewhere.'

A third way of expressing the future, the futurate present, as in example Ic), also exists in French. However, it occurs so rarely in our corpora that it was excluded from quantitative analysis.

Ic) Asteure comme Daddy, il sait en masse des histoires aussi. Si il y aurait moyen de toutes les écrire en bas, tu sais hein, comme ça, ils sont pas perdus hein. $(\mathrm{AC}-3)$

'Now like Daddy, he knows lots of stories, too. If there were a way of writing them down, you know eh, like that, they are not lost, eh.'

\section{I The meaning of the periphrastic and inflected future forms}

In the analyses that follow, we consider the periphrastic and inflected future forms as variants of the same grammatical variable. In other words, they are interpreted as having the same referential value. While they may be formally distinct, the function of both forms is to allow the speaker to refer to a future verbal action. This interpretation rests on the fact that in the contexts under study, the periphrastic and inflected forms can be used without altering the meaning of the utterance. In Labov's terms (Labov, I972: 27I), they are two ways of saying the same thing. It is true that, historically, numerous French grammarians have associated a rather complex set of nuances of meaning with each future form, though not uncontroversially (see Poplack and Turpin, I999 for a detailed discussion of the history of future marking in French). The most basic distinction said to distinguish the two is that the periphrastic is used when the future event is viewed as more immediate and when the speaker wishes to express greater interest and involvement with the event, along with greater certainty of its occurrence. However, as discussed by Poplack and Turpin (I999), little empirical evidence exists to support such a claim. In fact, an in-depth analysis of spoken data leads these researchers to conclude that both forms can occur in exactly the same context with the same meanings. This is certainly the case in our data since, as we will see in section 6 , both variants are readily used in temporally proximal and distal context, though to varying degrees. As such, potentially relevant distinctions present in the linguistic environment should therefore be looked upon as having a variable effect on variant choice, not a categorical one. Sankoff (I988, cited by Poplack and Turpin) suggests that while it may be possible for the linguist to imagine slight differences in the meaning of two linguistic forms upon reflection, there is no reason to believe that these differences are relevant to the speaker using language in a conversation. This same approach is advocated in the current study (cf. Nadasdi, 2000). 
Both the inflected and periphrastic futures have a long history in French. The periphrastic future was first used as a transparent verb of motion, but by the I 5 th century it was used colloquially to indicate prediction and came to be used this way in higher registers, including literary usage, during the I6th and I 7 th century. Studies of spoken French, from Bauche's I929 Le français populaire to more recent studies of European French (e.g. Lorenz, I989; Söll, I983) and Quebec French (e.g. Deshaies and Laforge, I98I; Emirkanian and Sankoff, I985), have found far more incidences of the periphrastic than the inflected future, leading researchers such as Poplack and Turpin (I999) to suggest that the inflected future is going the way of the passé simple, i.e. towards obsolescence. Some studies do suggest a split between the French of France and Quebec in this regard: for example, Jeanjean (I988) recorded a nearly even distribution of inflected and periphrastic futures in her quantitative study of Metropolitan French data collected by researchers in Aix-en-Provence, while Emirkanian and Sankoff's I985 study of Montreal French recorded the average use of inflected futures at approximately 20 per cent. Poplack and Turpin's own study of Ottawa-Hull French, which served as the model for our study, found the same proportions as did Emirkanian and Sankoff.

One objective of our study of future marking in Acadian French is to determine the relative proportion of the two forms of the future in this variety. We have shown in a number of recent studies (e.g. King, I994; King and Nadasdi, I997) that the morphosyntax of Acadian French differs in a number of important ways from that of Quebec and Ontario French. In some cases, it has undergone developments which have not taken place in those other North American French varieties (King, I994); in other cases, it exhibits more conservative usage, serving in many ways as a mirror on the past (King and Nadasdi, I997). We would not be surprised, then, if Acadian did not line up with other North American varieties in its treatment of future variants. Indeed, in some varieties of Acadian French (e.g. those of southeastern New Brunswick) the passé simple, mentioned earlier as perhaps a parallel case to the simple future, was in widespread use as recently as the late I940s (Haden, I948) while in some Nova Scotia varieties (Flikeid, I989) it still remains productive. This is in stark contrast with what one finds in Quebec and Ontario where, as in spoken French more generally, the passé simple has disappeared.

There is a second reason why we might predict greater use of inflected futures in Acadian French. This concerns the fact that Acadian preserves rich inflectional verbal morphology not found in Quebec or Ontario French. For instance, it retains the colloquial -ont suffix marking third person plural (present tense), as in 2a below, whereas in these other varieties the third person singular and plural are usually homophonous since orthographic -ent is phonetically null (cf. King and Nadasdi, I997). An inflected future, then, would be part of a general system of rich (or richer) inflectional morphology. Further, since the -ont suffix is also 


\section{Ruth King and Terry Nadasdi}

used in the third person plural for the inflected future, in combination with an infinitival form of the verb, as shown in $2 \mathrm{~b}$ ), we hypothesize that the Acadian system might promote retention of inflected future marking in a way that other French varieties, i.e., those which have lost the -ont suffix for other tenses, cannot.

2a) C'est pareil comme les bouteilles euh les bouteilles de de de Coke là, les bouteilles de pop, avant ils les aviont en en vitre hein puis ils explodiont. Mais asteure ils les faisont en plastique parce c'est meilleur parce.... c'est dangereux. (AC-2)

'It's the same with bottles uh bottles of of of Coke, bottles of pop, before they used to make them out of glass eh and they used to explode. But now they make them out of plastic because it's better because ... it's dangerous.'

2b) C'est les [oui] les vivants qui te feront mal. (AC-3)

'It's the [yes] the living who will do you harm.'

As can be seen in the examples in 2), the -ont suffix is present in a wide range of tenses, such as the imperfect, the present, the plus-que-parfait, the conditional, etc., e.g. ils parliont ('they used to speak'), ils parlont ('they speak'), ils aviont parlé ('they had spoken'), ils parleriont ('they would speak').

\section{THE DATA}

The data come from two Acadian communities located in the province of Prince Edward Island, Abram-Village and Saint-Louis, and one community in the province of Newfoundland, L'Anse-à-Canards. In previous work (e.g. King, 200o; King and Nadasdi, I998) we have shown that these Acadian varieties have similar grammars. Both Abram-Village and L'Anse-à-Canards are fishing villages with approximately three hundred residents while Saint-Louis is a fishing village with half that population. While English is the majority language in both provinces, all three communities are located in fairly isolated French enclaves. French is the majority language in both Abram-Village and L'Anse-à-Canards, although many younger speakers in L'Anse-à-Canards are English dominant. There is institutional support for French in both villages in the form of francophone cultural associations. In addition, Abram-Village has a French medium school, bank, postal services and shops whereas L'Anse-à-Canards residents are bussed to a nearby community for school, which is available in French and English, but other services are provided in English. Saint-Louis lacks such institutional support for French and indeed the community is undergoing language shift. While Standard French is of little importance to the lives of the vast majority of L'Anse-à-Canards and Saint-Louis residents, there is considerable variation among Abram-Village residents in terms of the linguistic marketplace, i.e. 'how speakers' economic activity, taken in its widest sense, requires or is necessarily associated with competence in the legitimized (or standard, elite, educated, etc.) language' (Sankoff and Laberge, I978; following Bourdieu's notion of language as symbolic capital). 
In I987, twenty-four Abram-Village residents and nineteen Saint-Louis residents ${ }^{1}$ were interviewed by native Acadian French speakers born and raised in each community, using conversation modules designed to elicit approximately two hours' worth of free conversation per individual. Speakers varied according to age, sex and position in the linguistic marketplace. In I988, the same methodology was used in L'Anse-à-Canards with interviews conducted with forty residents, with the exception that all of those interviewed would be regarded as having a low marketplace ranking. ${ }^{2}$ Only fully fluent French speakers were interviewed. For the present study, eight speakers were selected from each corpus, both male and female, matched in terms of marketplace ranking.

\section{I 'False' futures}

The first step in the present analysis was to eliminate morphological futures which do not refer to future time, as in 3) where we find the periphrastic future used to describe a habitual action and in 4) where we find a frozen expression involving the inflected future. ${ }^{3}$

3) C'était étrange parce c'est pas souvent qu'une personne va rêver du bon Jésus. $(\mathrm{AC}-3)$

'It was strange because it's not often that a person is going to dream about Jesus.'

4) Il était pas marié dans ce temps-là mais Prieur, il peddlait la graine à choux ... puis il l'amenait chez ... chez mon père, je dirons. (AC-2)

'He wasn't married in those days but Prieur, he used to peddle cabbage seed ... and he brought it to ... to my father's house, we'll say.'

3), then, does not involve the marking of future temporal reference, while 4) does not allow alternation between the inflected and the periphrastic future. Once such occurrences were excluded, the data were coded for a number of linguistic factors and submitted to multivariate analysis using GoldVarb2.

1 The lower number of Saint-Louis speakers interviewed was due to the serious decline of French in the community.

2 The Prince Edward Island corpus was constructed under the direction of Ruth King, with collaboration from Gary Butler on the research design. The Newfoundland corpus was constructed by Gary Butler. We thank him for allowing us access to this corpus.

${ }^{3}$ Since habituals are not instances of the variable, considerable caution should be exercised in making comparisons with studies which do not take this distinction into consideration. This is the case of Chevalier (I996), the only other study of Acadian French of which we are aware. This study found use of inflected future morphology to range from $7.9 \%$ to 37. $1 \%$ in the French of students from three regions of New Brunswick who responded to an attitudinal questionnaire. However, since three of eight sample sentences given clearly involved habituals we assume no effort was made to distinguish true future marking. 


\section{Ruth King and Terry Nadasdi}

\section{CONDITIONING FACTORS}

In our coding of the dependent variable, we initially distinguished two periphrastic futures, the aller + infinitive periphrastic form illustrated in ra) and the periphrastic involving the verb s'en aller. This second variant is shown in 5):

5) Bien, je dis, 'Maman,' je dis, 'avec le courage,' je dis...je dis 'je m'en vas l'essayer.' (AC-4)

'Well, I say, 'Mother,' I say, 'with courage,' I say ... I say 'I'm going to try it.'

Since no difference was found in the distribution of the two variants they were subsequently collapsed. We then followed the model of Poplack and Turpin who operationalized many of the factors said in the prescriptive and/or descriptive literature to motivate choice of the periphrastic versus the inflected future.

\section{I Temporal distance}

Poplack and Turpin note that according to traditional grammarians, the choice of the periphrastic over the inflected future is linked to the time at which the verbal action is to occur. Actions occurring shortly after the time of the utterance are thought to favour the periphrastic future. This same perspective is espoused in pedagogical grammars aimed at second language learners of French. For example, in describing the difference, Parmentier (I989: I72) writes:

'Dans la langue parlée, aller + infinitif tend à prendre la place du futur; toutefois, ils ne sont pas interchangeables: en particulier, il faut employer aller + infinitif ou le présent pour les faits qui se situent dans l'avenir immédiat, avec des adverbes comme immédiatement, tout de suite (même si ceux-ci sont sous-entendus) ..."4

Given previous claims that the periphrastic future is used more often to describe actions that are 'about to happen' or that will happen in the near future, we categorized verbs according to whether the action would happen within the hour (6a), within the day (6b), within the week (6c), or within a period longer than a week (6d). ${ }^{5}$ We also distinguished a fifth category (continual) to take into account events which began in the past, but which will continue in the future, as in 6(e):

6a) Je vas te donner une guess. (AV-23)

'I'll give you a guess.'

b) Je vais voir ça à soir parce tout le monde le voit. (AC-7)

'I'm going to see that this evening because everyone sees it.'

c) Elle va retourner en California jeudi qui vient. (AV-23)

'She is going to return to California next Thursday.'

${ }^{4}$ In the spoken language, aller + infinitive tends to replace the future: however, they are not interchangeable. In particular, one must use aller + infinitive or the present for events that will take place in the near future, with adverbs such as immediately, right away (even if they are implied)... (our translation).

5 Coding for these various categories was greatly facilitated by contextual cues, such as the adverbs in the examples given in 6 . 
d) J'aurai soixante et deux dans septembre, dans... dans décembre. (SL-30) 'I'll be sixty-two in September, in ... in December.'

e) Ils fumeront jusqu'à leur mort. (AV-25)

'They will smoke until their death.'

\subsection{Type of adverbial specification}

Drawing on a number of descriptive studies, Poplack and Turpin coded their data for whether or not the dependent variable occurred in the context of what they refer to as a specific time adverbial (such as ce matin 'this morning'), a non-specific time adverbial (such as plus tard 'later') or whether no such specification was present. Their results show that inflected futures are promoted by the presence of a nonspecific time adverbial and that futurate presents occur primarily with a specific time adverbial. In their interpretation of these results they suggest that the specific time adverbial disambiguates future versus present tense readings. Periphrastic futures, on the other hand, appeared to be favored in the context of no adverbial specification, as a kind of default option. We thus coded our data for this variable; in $7 \mathrm{a}$ ) we see specific time reference and in $7 \mathrm{~b}$ ) a non-specific time adverbial while in $7 \mathrm{c}$ ) there is no such temporal specification.

7a) 'De soir, on va avoir de la fun.' ${ }^{6}$ (SL-35)

'This evening, we are going to have fun.'

7b) Je pense qu'il le fera plus tard. (AC-8)

'I think he will do it later.'

7c) Je vas pas blâmer la jeunesse, moi!. (AC-25)

'I'm not going to blame the youth, me.'

\subsection{Contingency on a si clause}

The extant literature also points to a tendency to prefer inflected futures in contexts where one event is 'contingent' on another event. For the most part, such contingency is indicated by a si 'if' clause, as in examples $8 \mathrm{a}$ ) and 8b). In 8c) no such contingency is present.

8a) S'il s'en va de toi, bien [oui] il va mourir. (AC-3)

'If he goes away from you, well he is going to die.'

8b) Si t'as plus de familles anglaises, ils seront plus portés, les enfants, à parler anglais avec les autres (AV-I 8)

'If you have more English families, they will be more likely, the children, to speak English with others.'

8c) Le plus gros va gagner. (AV-23)

'The biggest one will win.'

${ }^{6}$ This evening is rendered à soir in Newfoundland French but de soir in Prince Edward Island French. 
This context has been taken into consideration in a number of studies since the contingent event is hypothetical, a context which traditional grammars have associated with use of the inflected future.

\subsection{Certainty/imminence}

Previous accounts of the distribution of periphrastic and inflected futures have drawn attention to the fact that the former is used more readily with events that are deemed more certain to occur. A variety of studies have captured this distinction with the notion of imminence, defined by Vet (I993) as 'a state at which the eventuality is impending', as in the examples in 9), where a is imminent and b is non-imminent:

9a) Je m'en vais t'arranger une tasse, une belle tasse de cocoa chaud, ça va te faire du bien. (AC-4)

'I'm going to make you a cup, a good cup of hot cocoa, it is going to do you good.'

9b) Je sais pas quand-ce-qu'elle [la guerre] arrêtera. (SL-25)

'I don't know when it [war] will stop.'

We have chosen to refer to this distinction as one of certainty since temporal distinctions are already taken into account by the independent variable referred to as temporal distance, discussed above. It should be noted that coding for this factor is challenging. In order to ensure consistency, the authors verified each other's coding. We also developed criteria for making the certain-uncertain decision. For example, if adding sans aucun doute 'without any doubt' did not make the event seem more certain to occur, we considered the case certain. If adding sans aucun doute did render the event more certain, it was coded as uncertain. Other contextual cues, such as the presence of peut-être 'perhaps' or me semble '(it) seems to me', helped in making these decisions.

\subsection{Grammatical person}

It has sometimes been suggested that the periphrastic future is more subjective than the inflected future. Poplack and Turpin also coded for this variable, hypothesising a split between first person, on the one hand, and second and third person. First person subjects, in their view, might be expected to promote periphrastic futures. We coded our data for all person/number possibilities, some examples of which are given in IO).

IOa) Je vais engager quelqu'un pour faire ça (AV-I6)

'I'm going to hire someone to do that.'

b) Tu peux demander ça à ton père et ta mère, je dis, eux sauront peut-être mieux que moi. (AC-7)

"You ask your father and mother,' I say, 'they will know better than me." 


\section{Back to the Future in Acadian French}

c) ils disont qu'il va faire laid. (AV-I6)

'They say it is going to be nasty.'

\subsection{Negation}

A large number of quantitative studies have found the presence of negation to contribute strongly to the presence of inflected futures, though, as Poplack and Turpin note, this factor has been largely ignored in non-quantitative work. One view, offered by Deshaies and Laforge (I98I), is that the increased hypothetical nature of negative contexts promotes use of inflected futures. Following the lead of these researchers and given the strong effect of this factor found in studies of Quebec French, we coded our data for negative versus non-negative, as shown in I I):

I Ia) Ils allont pas garder ça (AV-I2)

'They are not going to keep that.'

I Ib) Un jeune, ioù-est-ce qu'il va prendre l'argent? (AV-I9)

'A young person, where will he get the money?'

\subsection{Presence of quand}

Two additional variables coded for involved presence or absence of the wh-term quand 'when', specifically whether or not the dependent variable was found within a sentence containing a subordinate clause introduced by quand, and whether or not the variable was found within the subordinate clause which actually contained quand. The 'quand' variables were suggested by Chevalier (I996), who hypothesized, on the basis of her intuitions as a Québécoise working in an Acadian context, that the presence of quand might have a conditioning effect. ${ }^{7}$ These two factors are both illustrated in I2).

I2) Il a dit asteure: 'Demain matin quand ton père se levra, il verra la prison débarré...'

He said now: 'Tomorrow morning when your father gets up, he'll see the prison unlocked...' (SL-35)

\section{RESULTS}

Turning to the results of our study, let's first consider the overall frequency of the two forms, given in Table I and organized according to locality.

While the raw percentages show much higher incidences of inflected futures in the data for the two Prince Edward Island (hereafter PEI) communities' data than in the L'Anse-à-Canards, Newfoundland data, it is important to note that

${ }^{7}$ Chevalier did not hypothesise as to why this might obtain. 
Tableau I. Distribution of the two expressions of future temporal reference by locality

\begin{tabular}{lcc}
\hline \hline Locality & Periphrastic futures & Inflected futures \\
\hline St-Louis, PEI & $64(43 \%)$ & $85(57 \%)$ \\
Abram-Village, PEI & I3 I $(4 \mathrm{I} \%)$ & I9I $(59 \%)$ \\
L'Anse-à-Canards, NF & I28 $(60 \%)$ & $86(40 \%)$ \\
Totals & $323(47 \%)$ & $362(53 \%)$ \\
\hline \hline
\end{tabular}

multivariate analysis shows that this is not statistically significant. ${ }^{8}$ Given this result, it is unlikely that the variants of this variable correspond to a standard/vernacular distinction since French language education is much more prevalent in AbramVillage, one of the two PEI communities, as noted earlier. What is clear from these first results is that the data for all three Acadian communities show a far greater preponderance of inflected futures than have been found in quite a number of studies of other Canadian varieties. Poplack and Turpin's study of Ottawa-Hull French is, quantitatively speaking, in line with research conducted in Montreal and Quebec City: Poplack and Turpin found 73\% periphrastic futures, 20\% inflected futures, and $7 \%$ futurate presents. The Acadian communities show more robust use of the inflected future (53\%), so claims of its decline in Canadian French in general seem premature.

We turn now to the effects of various linguistic factors on choice of future marker. We will first review the findings of Poplack and Turpin because, in addition to their study being the most rigorous treatment of the topic in the literature, their findings in this regard, not merely the overall distribution of future marking, lead them to conclude that the inflected future seems to be on the way out, at least in colloquial speech. Briefly, the prime contributors to choice of one form over the other previously identified in grammars of Standard French were not found to have a significant effect on future marking in the Ottawa-Hull study: temporal distance was not found to distinguish periphrastic from inflected usage as both were favored in proximal contexts while only the futurate present was favored in distal contexts. The temporal distance factor was found to be highly correlated with the type of adverbial specification factor, in that proximal contexts tended to co-occur with non-specific adverbs, distal contexts with specific adverbs. Since this latter factor is most important for a variant we did not investigate because of its infrequency in our corpora, the futurate present, we will not go into these results further.

${ }^{8}$ As mentioned in section 4 the Newfoundland data is particularly rich in narratives. Since narratives involve the recounting of sequences of events in the temporal order in which they are purported to have occurred (see Labov, I982), this discourse genre may well promote more immediate contexts, with the result of a greater tendency towards periphrastic futures than in the Prince Edward Island corpora. 
A factor which is directly comparable to our own results is that Poplack and Turpin found imminence to have no significant effect on choice of the periphrastic versus the inflected future. Contingency, likewise, did not matter in the choice of periphrastic or inflected future in the Ottawa-Hull corpus, nor did grammatical person and number, aside from the fact that formal vous favored the inflected future, taken by Poplack and Turpin to mean that the inflected future has become a formal variant. Since our own corpora contained no instances of formal vous, most likely due to the informal nature of the interviews, we can make no comparison here. ${ }^{9}$ It turned out that negation did have a significant effect on variation in Ottawa-Hull: negative contexts strongly favored the inflected future, also a finding of Deshaies and Laforge (I98I) and Emirkanian and Sankoff (1985) for varieties of Quebec French and Lorenz (1989) for European French. Poplack and Turpin conclude that while the exact reason for the prominence of the inflected future in this context has led to considerable speculation, some of it contradictory, they stress that 'negative contexts ... are the only remaining loci in which the inflected future is used productively in Canadian French.' (p. I6)

We turn now to our Acadian results which reveal a very different scenario. These results are presented in Table 2 .

\section{I Temporal distance}

The most important contextual factor group for the future variable is temporal reference. There is strong evidence that the tendency noted in the standard grammars continues to exist in Acadian French, that is, verbs that indicate an action which is near, or about to happen, are expressed much more readily by the periphrastic future. While the exact definition of what constitutes 'near' is difficult to pin down, our results seem to suggest that anything thought to occur within a period shorter than a week falls into this category since there are no significant differences separating the categories of 'hour', 'day' and 'week'. In all of these instances, the periphrastic future is preferred in 75 per cent of actions that are to occur within the week. More distant events, i.e., those thought to occur at least a week from time of speech, favour the inflected future since the periphrastic is only used in in 40 per cent of such cases. The category for which the periphrastic future is highly disfavoured (I I per cent) is continual, i.e. those events existing in the present and which will continue in the future. All these results support the traditional appellation of futur proche for Acadian French.

\subsection{Certainty/imminence}

As discussed above, standard grammars of French point to a correlation between high use of periphrastic future and events that are likely or certain to occur. Our

9 This is likely a reflection of the interview context (the interviews were conducted by community insiders) rather than the complete absence of formal vous in the grammar of these speakers. 
Tableau 2. Variable rule analysis of the contribution of significant linguistic factors to the probability that the periphrastic future will be selected

\begin{tabular}{|c|c|c|c|c|}
\hline & $\begin{array}{l}\text { Factor } \\
\text { weight }\end{array}$ & $\mathrm{N}$ & Total & $\%$ \\
\hline \multicolumn{5}{|c|}{ Temporal reference } \\
\hline within hour & .689 & 70 & 90 & 78 \\
\hline within day & .644 & 36 & 50 & 72 \\
\hline within week & .678 & 35 & 49 & $7 \mathrm{I}$ \\
\hline longer than week & .479 & I 76 & 442 & 40 \\
\hline continual & .135 & 6 & 54 & I I \\
\hline \multicolumn{5}{|l|}{ Certainty } \\
\hline Uncertain & .387 & I 45 & 439 & 33 \\
\hline Certain & .695 & I 78 & 246 & 72 \\
\hline \multicolumn{5}{|c|}{ Presence of subordinate clause with "quand" } \\
\hline yes &. $\mathrm{I} 32$ & 2 & I6 & I 3 \\
\hline no & .5 I I & $32 \mathrm{I}$ & 669 & 48 \\
\hline \multicolumn{5}{|c|}{ Factors not selected as significant } \\
\hline \multicolumn{5}{|c|}{ Type of adverbial specification } \\
\hline \multicolumn{5}{|l|}{ Contingency } \\
\hline \multicolumn{5}{|c|}{ Grammatical person } \\
\hline Negation & & & & \\
\hline
\end{tabular}

sig. $=.009$.

results reveal that such a correlation holds for the Acadian French varieties we have studied since 72 per cent of certain events are indicated by the periphrastic form, whereas only 33 per cent of uncertain events are so expressed. This is by no means categorical, but the tendency does exist and produces the second most important influence on variation.

\subsection{Presence of quand}

The Chevalier hypothesis concerning the effect of 'quand' received some support: the presence of a subordinate clause containing 'quand' promotes use of the inflected future in the main clause (e.g. 'when he gets up, he will get dressed'). While there are not a lot of data here (only sixteen tokens), presence of quand did provide a favoring environment. In many, but not all, of these tokens, the event in the main clause was contingent upon the event in the subordinate clause. It would appear, then, that when there is a sequence of two future events the second event is more likely to be realised by the inflected future. This obtains regardless of how the future is marked in the subordinate clause. This of course is reminiscent of the results for 


\section{Back to the Future in Acadian French}

temporal distance since the further in the future an event is, the more likely it will be rendered by the inflected future.

\subsection{Linguistic factors not selected}

The following factor groups were not found to exercise a significant influence on variant choice: a) adverbial specification; b) contingency (in an 'if' clause); c) grammatical person and d) negation. It is in fact not surprising that though adverbial specification is relevant for other varieties of Canadian French, it is not relevant for Acadian. Recall first that in Poplack and Turpin's study the presence of a time-specific adverb correlated positively with the futurate present. However, since this variant is quite infrequent in our corpus, it is unlikely that adverbial specification would be relevant. Events contingent on 'si-clauses' also proved to play no role in this case of variation. So while traditional grammars point to a link between the inflected future and a hypothetical event tied to an 'if' clause, our study of Acadian French shows no evidence of such a link. Our reason for controlling for grammatical person was that some researchers have posited that the periphrastic future is more subjective and therefore should occur more readily with first person subjects (cf. Blanche-Benveniste, I990; Jeanjean, I988); however our data does not support such a claim.

The lack of a significant effect for negative contexts deserves comment since this is in striking contrast to findings for other Canadian varieties. The reason for this is not straightforward, but no more so than the positive correlation found between use of the inflected future and negative contexts in non-Acadian varieties. However, if we accept as valid the relationship between certainty and periphrastic futures noted in traditional grammars and further assume that negative sentences are considered, by their very nature, as less certain, an explanation seems possible. Note that such a relationship does seem to hold for our data, since while 39 per cent of positive tokens were coded 'certain', only is per cent of negative ones were. We therefore suggest that while Poplack and Turpin (I999) did not find 'certainty' or 'imminence' a significant effect for the future variable in Ottawa-Hull French, it may have played an important role at some earlier stage in the history of this variety. If the association between uncertainty and negation has indeed become quite strong, negation itself may well have become the important contextual factor in other varieties of Canadian French. Such a development has clearly not occurred in the Acadian varieties we have investigated.

\section{CONCLUSION}

Our data reveal that the inflected future is still widely used in three varieties of Acadian French spoken in two Atlantic Provinces, varieties which have very similar grammars (with rich verbal morphology) but whose social circumstances differ. More precisely, we found a general rate of occurrence of 53 per cent for the inflected future, a form used only 20 per cent of the time in other varieties of Canadian French. We also find that while some contextual factors identified 


\section{Ruth King and Terry Nadasdi}

by traditional grammars as relevant for the future variable may not be pertinent for Quebec French, they still exercise an important influence on the variable in Acadian. This is true in the case of both temporal proximity and certainty since, in Acadian French, proximal and certain contexts promote the use of the periphrastic future, though no such correlation has been found to exist in other Canadian varieties. Thus, in yet another way Acadian French displays different patterns of morphosyntactic variation and change than its better known neighbor, Quebec French, and here shows itself to be more conservative.

Authors' addresses:

T. Nadasdi

Modern Languages and Cultural Studies

University of Alberta

Edmonton, Alberta

Canada
R. King

Languages, Literatures and Linguistics York University

Toronto, Ontario

Canada

\section{REFERENCES}

Bauche, H. (1929). Le Langage populaire. Paris: Payot.

Blanche-Benveniste, C. et al. (I990). Le Français parlé: Etudes grammaticales. Paris: Editions du Centre national de la recherche scientifique.

Chevalier, G. (I996). L'emploi des formes du futur dans le parler acadien du sud-est du Nouveau-Brunswick. Les Acadiens et leur(s) langues(s): quand le français est minoritaire. Moncton: CRLA, pp. 75-89.

Deshaies, D. and Laforge, E. (I98I). Le futur simple et le futur proche dans le français parlé dans la ville de Québec. Langues et linguistiques, 7: 23-37.

Emirkanian, L. and Sankoff, D. (1985). Le futur 'simple' et le futur 'proche'. In: M. Lemieux and H. Cedergren (eds.), Les Tendances dynamiques du français parlé à Montréal. Vol. I. Québec: Office de la langue française, pp. I89-204.

Flikeid, K. (I989). Recherches sociolinguistiques sur les parlers acadiens du NouveauBrunswick et de la Nouvelle-Ecosse. In: R. Mougeon and E. Beniak (eds.), Le Français parlé hors Québec. Québec: Presses de l’Université Laval, pp. I83-200.

Haden, E. (1948). La petite Cendrillouse, version acadienne de Cendrillon: Etude linguistique. Archives de folklore, 3: $2 \mathrm{I}-34$.

Jeanjean, C. (1988). Le futur simple et le futur périphrastique. Etude distributionnelle. In: C. Blanche-Benveniste, A. Cheurel and M. Gross (eds.), Grammaire et histoire de la grammaire, Hommage à la mémoire de Jean Stéfanini. Aix-en-Provence: L'Université de Provence, pp. $235-257$.

King, R. (I994). Subject-Verb Agreement in Newfoundland French. Language Variation and Change, 23/3: 239-253.

King, R. (2000). The Lexical Basis of Grammatical Borrowing: A Prince Edward Island French Case Study. Amsterdam \& Philadelphia: John Benjamins.

King, R. and Nadasdi, T. (I996). Sorting Out Morphosyntactic Variation in Acadian French: The Importance of the Linguistic Marketplace. Sociolinguistic Variation: Data, Theory and Method. Selected Papers from NWAV23 at Stanford. Stanford: Centre for the Study of Language and Information (CSLI), pp. I I3-I28. 
King, R. and Nadasdi, T. (I997). Left Dislocation, Number Marking and Canadian French. Probus, 9/3: 267-284.

King, R. and Nadasdi, T. (I998). On Variable Use of Traditional Acadian Verbal Morphology in Prince Edward Island French. In: J. Jensen and G. Van Herk (eds.), Proceedings of the Annual Meeting of the Canadian Linguistic Association. Ottawa: University of Ottawa, pp. I69-I78.

Labov, W. (I972). Sociolinguistic Patterns. Philadelphia: University of Pennsylvania Press.

Labov, W. (1982). Speech Actions and Reactions in Personal Narratives. In: D. Tannen (ed.), Analyzing Discourse: Text and Talk. Washington, D.C.: Georgetown University Press.

Lorenz, B. (1989). Die Konkurrenz zwischen dem futur simple und dem future périphrastique im gesprochenen Französisch der Gegenwart. Munich: Kleinheinrich.

Nadasdi, T. (2000). Variation grammaticale et langue minoritaire: le cas des pronoms clitiques en français ontarien. Munchen: LinCom Europa.

Parmentier, M. (1989). Mise au point. Toronto: Holt, Rinehart and Winston.

Poplack, S. and Turpin, D. (I999). Does the FUTUR have a Future in (Canadian) French? Probus, II/I: I34-I64.

Sankoff, D. and Laberge, S. (I978). The linguistic market and the statistical explanation of variability. In: D. Sankoff (ed.), Linguistic Variation Models and Methods. New York: Academic Press, pp. 239-250.

Söll, L. (1983). De la concurrence du futur simple et du futur proche en français moderne. In: F.-J. Hausmann (ed.), Etudes de grammaire française descriptive. Heidelberg: Julius Groos Verlag.

Vet, C. (I993). Conditions d'emploi et interprétation des temps futur du français. Verbum, 4: 7I-84. 